\title{
THE IMPLEMENTATION OF TRAINING IN FAMILY INCOME INCREASING BUSINESS PROGRAM CASE STUDY IN PENDRIKAN LOR VILLAGE SEMARANG CITY 2017
}

\author{
Mohammad Soko Marhendi \\ Faculty of Social and Political Science, University of Indonesia, marhendi2408@gmail.com \\ Indra Lestari Fawzi \\ Faculty of Social and Political Science, University of Indonesia, inle_bon@yahoo.co.id
}

\begin{abstract}
Until now poverty still exists and is found in people in Java. Central Java is the province with the largest poverty depth index in Java. For this reason, sustainable empowerment needs to be sought and used to overcome the problem of poverty. One of the empowerment programs carried out by the regional government is the Family Income Improvement Business Program (UP2K). This study uses a qualitative approach that aims to describe the empowerment process that has been carried out especially at the stage of the training program. The type of research is descriptive. The results obtained in the training research were carried out by determining training needs, designing training programs, and evaluating program effectiveness. If this stage is carried out it will have a positive impact on the family's economic capacity. The driving factors of the implementation of the training include adaptive and competent trainers and supporting facilities and infrastructure. However, in the implementation, there were still obstacles in the field, including low education of participants and the timing of training which often clashed with the participants' activities. The suggested solution is to use competent trainers and socialize before training.
\end{abstract}

Keywords: Poverty; Empowerment; Training; Government program, UP 2 K 


\section{INTRODUCTION}

Indonesia, especially in Java, has a very dense population. Population density itself creates various social problems. One of the causes of social problems is economic factors. Poverty and inequality are examples of social problems that arise due to economic factors.

Poverty is seen as an economic inability to meet basic food and non-food needs, measured in terms of expenditure. (BPS, 2017). Poverty has resulted in people being unable to meet their daily needs. Indonesia's population of 60-70 percent is in Java, this causes inequality.
Poverty is a problem in development characterized by unemployment and underdevelopment, which then increases to inequality (Kartasasmita, 1993).

In addition to the poverty line, other dimensions that need attention, namely the level of depth and severity of poverty. In addition to being able to reduce the number of poor people, the success of poverty alleviation policies is also measured by the magnitude of changes in the level of depth and severity of poverty.

Table 1. Depth poverty index and poverty severity index in provinces on Java

\begin{tabular}{|c|c|c|c|c|}
\hline \multirow{2}{*}{ Province } & \multicolumn{2}{|c|}{ Depth Poverty Index } & \multicolumn{2}{c|}{ Poverty Severity Index } \\
\cline { 2 - 5 } & March 2017 & September 2017 & $\begin{array}{c}\text { March } \\
2017\end{array}$ & September 2017 \\
\hline Jakarta & 0,49 & 0.61 & 0,1 & 0,15 \\
\hline West Java & 1,45 & 1,39 & 0,37 & 0,35 \\
\hline Central Java & 2,21 & 2,12 & 0,57 & 0,55 \\
\hline East Java & 1,87 & 2,09 & 0,45 & 0,56 \\
\hline Yogyakarta & 2,19 & 0,78 & 0,55 & 0,46 \\
\hline Banten & 0.86 & 1,79 & 0,19 & 0,16 \\
\hline
\end{tabular}

Source: BPS 2017

Central Java Province still has the highest average of all provinces in Java, with a range of 0.56 percent. While the depth index of poverty in Central Java Province in 2017 was highest in all Provinces in Java, which was around 2.21, although in the following semester it decreased by 0.9 percent.
In Central Java Province consists of 29 Regencies and 6 Cities. From regencies and cities in Central Java Province have a variety of depth and severity indices of poverty. From the BPS Release in 2017. Semarang had the smallest Poverty Depth Rate of 0.54 percent, while the smallest Poverty Severity Index was also achieved by Semarang with 0.12 percent. Semarang has a 
smaller Depth and Severity Index than at the regional and national levels.

To reduce inequality and poverty, the government created an empowerment program, namely the PKK Family Income Improvement Program (UP2K PKK Program) whose implementation was regulated in the Ministry of Home Affairs Decree No. 53 B of 1993 concerning the PK2 UP2K Program guidelines. The UP2K program according to Minister of Home Affairs Decree No. 53 B of 1993 concerning the PK2 UP2K Program guidelines are:

1. All economic business managed by the family either individually or in groups with capital sourced from the Instruction Assistance and Rural Development or other assistance from the government, the country's foreign aid, as well as from nongovernmental own.

2. An economic effort is a form of business activity that is part of the implementation of the 10 PKK Principal Programs as a cooperative effort to increase family income in the context of efforts to achieve family welfare (UP2K PKK Administrative Guidelines, 1993)
Efforts to Increase Family Income (UP2K) PKK at the household level is an option and is a very important first step in the development of economic empowerment.

According to the Chairman of the research location in Semarang because it is one of the cities in Central Java that has the Poverty Depth Index and the Poverty Severity Index which is the highest among other provinces in Java in 2017. Besides, Semarang City has become the best UP2 K at the national level in 2017 with the title of the Main Pakarti I at the National Level, the best implementing UP2K PKK. As for those representing Semarang in the 2017 UP2K competition, Pendrikan Lor is the location of this research.

UP2K, the key factor for winning at the national level UP2K competition is the training activities of UP2K members (UP2K Chairman, initial interview, 27 February 2019). For this reason, this study aims to find out the implementation of the PKK Family Income Increase (UP2K PKK) training program. Also, it is also necessary to know the driving and inhibiting factors in the implementation of training in the UP2K program in the Pendrikan Lor Village.

Early \& Glen Maye (2000: 119) argued that Empowerment as a construct can be 
understood in the perspective of strength in the family, where the main purpose of intervention with family reflects to create opportunities for competencies that must be learned or discovered, environmental modification, and advocacy.

According to (Cox, 2000; Cox \& Parsons, 1994). "Empowerment has come to imply a process whereby individuals gain control over their own lives by influencing their interpersonal and social environments" (Singh. 1995:85)

According to Dreier (1996: 121-122), there are three strategies to explain community empowerment

"Community organizing involves mobilizing people to combat common problems and to increase their voice in institutions and decisions that affect their lives and communities. Community-based development involves neighborhood-based efforts to improve an area's physical and economic condition. Community-based service provision involves neighborhoodlevel efforts to deliver social services that will improve people's lives and opportunities (often called "human capital") within a neighborhood."

In line with that, empowerment as a development strategy is explained by
Kartasasmita (1996: 144) that "Empowerment is an effort to build power by encouraging, motivating, and raising awareness of its potential and trying to develop it".

One form of empowerment is training. Training according to Simamora (1999) is a series of activities designed to improve skills, knowledge, experience or changes in one's attitude. Then according to Sikula Andrew (1981) "Training is short term educational process utilizing a systematic and organized procedure by which non-managerial personnel learns technical knowledge and skills for a definitive purpose”. Based on these opinions, training is a short-term educational process with systematic and organized procedures to study knowledge, technical skills for limited purposes.

According to Gomes (2003: 204), there are three main stages in training and development, namely:

1. Assessing training needs

The purpose of determining this training need is to gather as much relevant information as possible to find out and determine the need for training in the organization. 
2. Designing a training program

In designing training programs that are based on the information gathered, they will know what knowledge or skills need to be improved in the organization.

3. Evaluating training program effectiveness

Training is expected to improve the lack of skills. Organizational members must realize the need for new information or learn new skills, and maintain the desire to learn.

According to Kirkpatrick (2006), several factors influence the implementation of training in a program. These factors are grouped into several parts, among others are training participants, delivery of material, training programs, and facilities and infrastructure that support the implementation of training.

Kirkpatrick explained that the training program was based on the needs of the participants. If the program does not meet the needs of the participants, it will affect the results of the evaluation in the future. There are several ways to determine training needs including a practical approach to the stakeholders involved. In addition to the training participants' needs, the selection of training participants greatly influences the success of the training program.

he submission of material in the training will affect the success of the training. The most important thing in delivering material during training is the selection of instructors. Instructors are educational staff and trainers who guide and deliver material both theory and practice to training participants during the training. Each instructor must meet the qualifications of knowledge, skills, attitudes, methodologies needed to train participants according to their expertise. Kirkpatrick explained that in each training must choose an effective instructor. Required qualifications are knowledge of the subject and the ability to communicate effectively. Other qualifications needed are the desire to teach, group knowledge, the ability to facilitate discussion in a workshop, and the ability to build relationships with groups.

Training programs must be developed to create systematic training. The training program includes training benefits, types of training, training content, and evaluation of training programs. Facilities and infrastructure that affect the implementation of training include equipment, facilities, and training committee. 
Welfare itself according to the Universal Declaration of Human Rights in Tiwari (2012: 64)

"the Article 25 of the Universal Declaration of Human Rights has provided a person or an individual with "the right to a standard of living adequate for the health and well-being of himself and of his family, including food, clothing, housing and medical care and necessary social services, and the right to security in the event of unemployment, sickness, disability, widowhood, old age or other lack of livelihood in circumstances beyond his control.'(United Nations, 2010 UDHR)"

\section{METHOD}

This research aimed to look at describing the training carried out by the UP2K program in community empowerment. For this reason, the approach used is qualitative. According to Bogdan \& Biklen, S. (1992: 21-22) a qualitative approach was also chosen because it can produce in-depth descriptions of speech, writing, and observable behaviors of certain individuals, groups, and communities in a comprehensive context. While the type of research is descriptive because the purpose is to describe the implementation of training in the UP2K program. The location chosen for this study was in the Pendrikan Lor Village, Semarang. The selection of Pendrikan Lor Village was due to represent the City of Semarang in the 2017 National UP2K competition with the title of the Main Pakarti I National Level best implementer UP2K PKK.

The selection of informants in this research used a purposive sampling technique with the criteria of knowing about the implementation of UP2K program training in Semarang, both from the aspects of policy, planning, and implementation. The informants in this research were Semarang City UP2K, UP2K Cadre Pendrikan Lor Village Semarang, and UP2K Members Pendrikan Lor Village Semarang.

Data collection is carried out through literature studies to obtain secondary data in the form of articles in journals, news, reports, mass media, government reports, and previous studies related to the Family Income Improvement Effort (UP2K) in Pendrikan Lor Village. 
To obtain primary data through in-depth interviews using guidelines for interviewing the research informants mentioned above. Besides, direct observation was also carried out using observation guidelines to observe attendance in training, activeness in training, and behavior of individuals and groups involved in the Family Income Improvement Business (UP2K) training held at Pendrikan Lor Village.

\section{RESULT}

\section{The Implementation of UP2K Training}

The first informant was the UP2K Chairperson of Semarang. So far the UP2K program has conducted various training that supports UP2K members. "The training carried out by the Semarang City UP2K included the UP2K Bimtek on UP2K administration, cooperatives, food management, packaging, marketing, handicraft, and batik training". Usually, UP2K collaborates with related agencies for training. "UP2K Semarang often collaborates with related agencies to help carry out training such as cooperative services to help with food processing training, health services regarding packaging and hygiene and nutrition of food".

The second informant was Ms. D, who owned a grocery stall business that had been running since 2010. She attended the UP2K training, which was cooking training, she took part in training in making spring rolls, corobikan (a kind of market snack cake), making cookies, and meatballs. Mrs. D considers the training carried out by the UP2K program useful for her, she claimed to have gained new knowledge and skills and became aware of how to make dishes that were taught correctly and the results were also good. But the training did not add to his income directly, because Mrs. D only made dishes that were taught in training for her family and siblings only, but was not marketed. The reason why it's not marketed is "Still not confident to be marketed, it still feels different, it's good, sometimes it's not (inconsistent), just as scared as the neighbors, because there are neighbors here who sell it”. Even though Mrs. D did not get any additional income directly, but indirectly Mrs. D got income from her UP2K friends who became fried food or cake sellers thanks 
to the training, because UP2K's Mrs. D's friends bought their raw materials at Mrs. D's stall "Alhamdulillah, they are shopping here, there are those who buy flour, eggs, gas, cooking oil, sometimes even those who buy vegetables at the market". This resulted in a significant increase in Mrs. D's income "Not bad if a day can be around 200-400 thousand". Usually, some of the profits are used as business capital, while others are for daily needs. There is one interesting thing, it turns out that by taking part in this training, it can reduce expenses from Mrs. D's family. "instead of I bought meatballs Rp. 10,000 for one person, I can make my own meatballs with 50,000 can for a whole family of five meals a day."

The third informant is $\mathrm{Mr}$. S, he has a small food sales business (fried food). Bapak S has a stall near the school and the main market is school children. Mr. $\mathrm{S}$ attended the UP2K training in the form of food processing, namely making lumpia and corobikan (market snack cake) and making meatballs. At first, he was rather troubled dividing his time between selling and training until finally, he decided to close his shop and choose to sell. He admitted that before attending the training he only sold a few types of fried foods" At first I used to sell only tempe mendoan, tofu susur (tofu vegetable contents), with cassava and fried bananas. After attending the training add the menu, add spring rolls and know meatballs. Alhamdulillah, now even spring rolls and know the tofu meatball sell well". According to Mr. S, his stall has benefited more after attending training from UP2K. Previously, Mr. S admitted that he had difficulty and was lazy to make spring rolls because according to $\mathrm{Mr}$. $\mathrm{S}$, it was complicated because of the smell of the bamboo shoots, it turned out that after attending the training he admitted that making spring rolls was easy to knowhow. "So yesterday when the training was given, it was said that boiling bamboo shoots should be given a little alum, and after being dried it was roasted (fried without using oil) with low heat so that the smell of bamboo shoots could disappear". In addition to the process of making bamboo shoots, $\mathrm{Mr}$. S also modified the meatball recipe obtained from UP2K training and made tofu meatballs from recipes he had 
modified." I modified that recipe for my meatballs. I modified it from the recipe for UP2K training, if at the UP $2 K$ the meatball and meat ratio was 5: 1 if my recipe, I reduced it to 2 slices of meat and 3 sago flour continued to add a little, and made special My Tofu meatballs are different from the other is that the meatballs are fried using a flour solution so after frying it becomes crispy". After attending UP2K training and applying the results of the training, and with the addition of two new products in the form of spring rolls and Tofu Meatball, Mr. S fried stalls were increasingly crowded with buyers and the two products were the most purchased by Pak $\mathrm{S}$ customers. more increasing "first before there is a spring roll menu and tofu meatballs a day's income between 100-200 thousand after there is a new menu, the income can reach 200-600 thousand per day, not to mention if you are fasting like this can be up to one million". With the increase in income, Mr. S can repair his stall, which used to be a regular stall from a wooden table, now he can buy a new stall in the form of a cart and glass, plus an aluminum table with glass to sell his fried food. Mr. S can also buy a motorbike that is used to shop for daily trading needs to market and buy a cellphone that can be used to receive calls from customers who want to order fried foods and through that cellphone, $\mathrm{Mr} . \mathrm{S}$ is also looking for inspiration and information about the current trend of food. From here, Mr. S makes Tahu mercon as his new menu.

\section{Driving and inhibiting factors}

Conducting the training in the UP2K program the results of the study found that there were factors that could be driving factors \& inhibitors.

Obstacle factor

"the inhibiting factor in conducting $U P 2 K$ program training is usually a low level of education / unable to read, besides the time factor, often training hours clash with other participants' activities which results in the absence of participants." (Chairman of Semarang City UP2K on February 27, 2019)

Mrs. D said the inhibiting factors in the implementation of the training included "If they do not understand the trainer usually immediately instructs the practice so 
the trainer gives instructions and they can follow". (Mrs. D, UP2K Management, Grocery shop business, May 18, 2019)

The inhibiting factor for Mr. S is as follows "I do a trade if I take five days off, what will my wife's child eat? Yesterday I suggested the exercise was made twice a week or once a week but it seems difficult to happen" (Mr. S, Fried Food Business, Participant in training on making meatballs and spring rolls, May 25, 2019)

The inhibiting factors that arise in the implementation of UP2K program training in Pendrikan Lor Village include the low level of education of participants and the timing of the training that clashes with the activities of participants.

\section{Driving Factor}

As for the driving factors include "the trainer is good and patient in facing the participants who are not (not understanding) besides that the training curriculum is interactive and has more practice than the theory, the trainers also carry the equipment so the mothers (participants) just come and join the training, plus active cadres who are running around (encouraging them to take part in training)" (Chairman of Semarang City UP2K on February 27, 2019)

Another driving factor, as expressed by Mr. S "yesterday when there was training, there was Ms. JS who really couldn't read and write, so the teacher (the trainer) was immediately told to practice while being taught and given instructions, the trainer also patiently listened to our questions. Mr. S added. "So we trained just to bring the body, everything was provided from UP $2 K$. In fact, we are also given books and pens to take notes.” (Mr. S, Fried Food Business, Participant in training on making meatballs and spring rolls, May 25, 2019)

The driving factors that emerged in the implementation of UP2K program training in Pendrikan Lor Village included competent trainers and understanding the situation and conditions of the participants, UP2K management 
(cadres) also had high dedication, and in training, all facilities and infrastructure were provided by UP2K management.

\section{DISCUSSION}

\section{The Implementation of UP2K Training}

According to Kartasasmita (1996: 144)

"Empowerment is an effort to build power by encouraging, motivating, and raising awareness of its potential and trying to develop it." The UP2K program also tries to explore the potential of family members through mentoring and developing it through training and building power by encouraging, motivating raising awareness of the potential of UP2K members through UP2K cadres. Empowerment efforts through the UP2K program through training activities in the Pendrikan Lor Village have the following path:

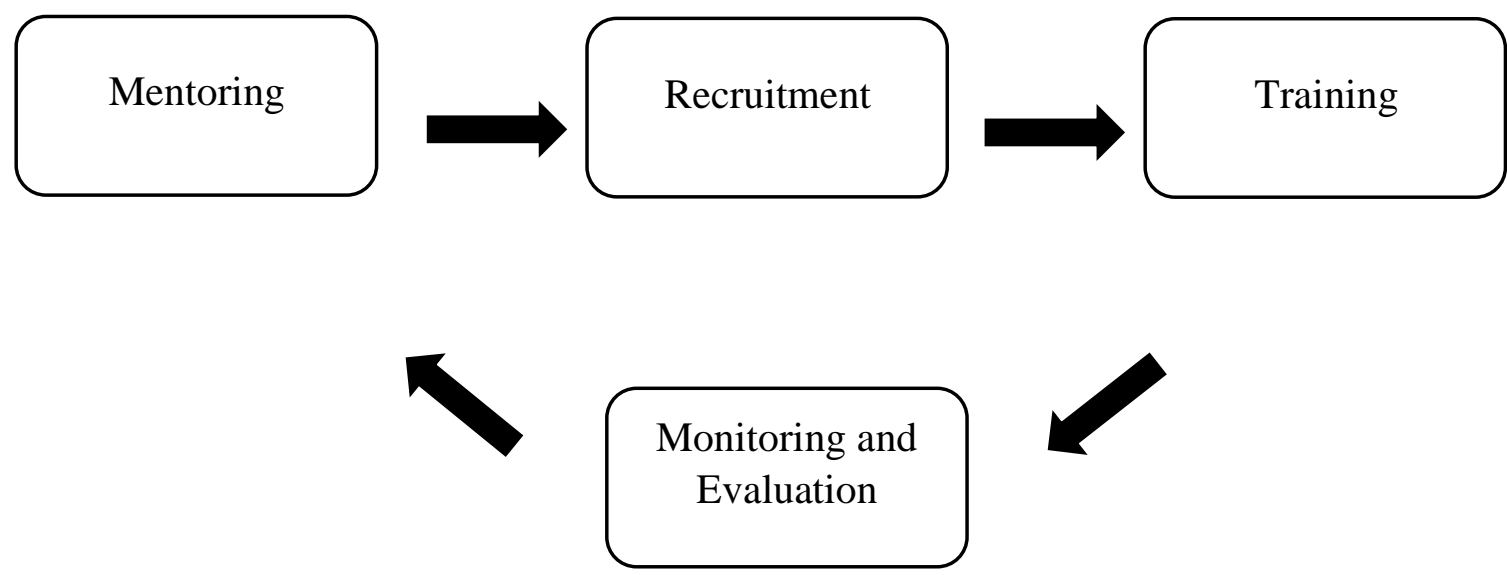

Picture 1: The flow of UP2K training activities in Pendrikan Lor Village Semarang Source: The researchers processed it from the interview results of Semarang City UP2K Chairperson on February 27, 2019

1. Mentoring

Mentoring is carried out regularly, usually, there is a monthly meeting which is also a means for mentoring or assistance carried out by groups per RW or individual. The companion here comes from the Village UP2K cadre. The assistance function here is to provide technical and non-technical guidance to UP2K groups in the context of business development starting from planning, implementation to reporting. In addition, mentoring is used to see the determination of training needs by collecting as much relevant information from UP2K members as possible 
to find out and determine the need for training, as well as the type of training needed.

2. Training Recruitment

Registering UP2K members who will take part in the training is usually recorded by UP2K cadres. Usually at the same time given an invitation for socialization which will later discuss the time and place of training. In this training recruitment, the type of training that will be carried out has been ascertained. If the number of participants is limited, then the priority is UP2K members who have similar business with the training to be carried out.

\section{Training}

Training is usually carried out after socialization for the determination of time, place and duration of training. The training carried out by UP2K internally was the UP2K bimtek on UP2K administration. while other training usually cooperates with related agencies such as the Cooperative and UMKM Service providing training on cooperatives, food processing, packaging, marketing, crafts, and batik. The health office also provides training in food hygiene and packaging. In training, the practice is more than theory. So that UP2K members can get experience making a production item. Usually, there are stages in training.

The first is the theory stage where at this stage theory, tips, and tricks are given in making production items. The second stage is the practice of mentoring. At this stage the UP2K members practiced the production of production materials with the assistance of trainers and were still directed by the trainers, after completion of the practice the members would collect the products that had been made to be assessed by the trainers, then the trainers would provide input related to the production items. The third stage is independent practice, here UP2K members immediately practice the production of manufactured goods without being given assistance by trainers.

4. Monitoring and Evaluation

Monitoring training evaluations are usually done after members have completed each stage of the training. And when the training was over through the mentoring mechanism so that the developments and obstacles faced by UP2K members could be known and solutions were found together.

Associated with the three main stages in training and development according to Gomes (2003: 204), the UP2K training can be analyzed as follows:

1. Assessing training needs

In the UP2K program, the determination of training needs was carried out at the mentoring stage, when the facilitators were, in this case, UP2K cadres gathered information about what skills or knowledge were needed to develop the potential of their UP2K members.

2. Designing a training program

In designing the UP2K training, information obtained from UP2K members through mentoring by UP2K Cadres was processed and formulated what skills and knowledge will be made in the training, and contacted the relevant offices to create a joint training curriculum which will be disseminated to UP2K members.

3. Evaluating training program effectiveness 
With the training that is compiled using information taken from UP2K members hope can improve the lack of skills and knowledge as well as obtain feedback in order to see the effectiveness of the program obtained from periodic evaluations.

\section{Driving and inhibiting factors}

Then to see the driving factors and UP2K inhibitors will be analyzed using the theory revealed by Kirkpatrick (2006) regarding the factors that influence the implementation of training in a program. These factors are grouped into several parts, among others are trainees, delivery of material, training programs, and facilities and infrastructure that support the implementation of training.

Inhibiting factor In the UP2K training, the participants themselves had a low education level and could not read so the training often lasted a long time because they had to repeat it until the participants understood. The solution is to change the format of the training from the lecture to more practice so that participants can immediately do it according to the instructions of the trainer. As told by Ms. D "If they don't understand, usually the trainer immediately instructs the practice so the trainer gives instructions and they can follow". The next inhibiting factor comes from the training program, usually, training is made in a row without any pauses, this results in a decrease in the level of the arrival of participants because participants have different agendas and routines. This is like the testimony of Mr. S "I do a trade if I take five days off, what will my wife's child eat?
Yesterday I suggested the exercise was made twice a week or once a week but it seems difficult to happen". The solution that can be done is to hold socialization first and state the ability of the participants to take part in the training and accommodate the training time suggested by the participants.

Driving Factor in UP2K training is a material delivery factor. Submission of material, in this case, is the ability of trainers who are adaptive and flexible in the delivery of material, after knowing that there are participants who cannot read, the trainer decides to practice immediately while giving instructions so that it does not become a significant obstacle. As stated by Mr. S "yesterday when there was training, there was Ms. JS who really couldn't read and write, so the teacher was immediately told to practice while being taught and given instructions, the trainer also patiently listened to our questions".

Other driving factors come from supporting facilities and infrastructure. In this case, the equipment provided by the committee such as cooking utensils, raw materials, stoves, and others. This is very helpful for participants because it eases the burden of participants because they do not need to bring their own equipment. As stated by Mr. S. "so we just took the training, all of it was provided from UP $2 K$. In fact, we are also given books and pens to take notes.".

\section{CONCLUSION}

Training in the UP2K Program has increased the capacity of participants. The training provides knowledge, skills, and attitudes to make changes to the business 
owned by trainees so they can increase income for the welfare of their families.

In conducting the training, UP2K conducted a determination of the training needs carried out during mentoring at the beginning of the program. When mentoring, UP2K members have given the opportunity to share the progress of their business, as well as the obstacles they experienced. From there UP2K administrators have information on training needs which will later be submitted to the City UP2K to be followed up on the information. Having information from the Special Group, the City UP2K formulates and designs the type, curriculum, time and place where the training will take place. When designing UP2K training coordinated with relevant stakeholders. One of them is the offices in the Semarang City Government. After the training is carried out, an activity evaluation is carried out. By carrying out evaluations it is expected that members learn new knowledge, skills, and attitudes in order to achieve training objectives.

In its implementation, there were found several factors that could be driving and inhibiting. Low levels of education such as participants cannot read and saturation of participants in participating in training which without interruption is a limiting factor. The ability of adaptive and flexible trainers is a solution that can support the course of training. While the other driving factor is the availability of advice and infrastructure that supports the implementation of training.

\section{REFERENCES}

Andrew E. Sikula, (1981), Personal Administration and Human
Resources Management”. John Wiley $\&$ Sons, Inc

Bogdan, R \& Biklen, S. (1992). Qualitative Research for Education. Boston: Allyn anda Bacon.

Dreier, P. (1996). Community empowerment strategies: The limits and potential of community organizing in urban neigborhoods. Cityscape: A Journal of Policy Development and Research, Volume 2, Number 2, May, 121-159.

Early, T. \& Gleen Maye. (2000). Valuing families: Social work practice with families from a strengths perspective. Social Work, Vol. 45, No. 2, 118-130.

Gomes, Faustino Cardoso. 2003. Manajemen Sumber Daya Manusia. Jakarta: Andi Offset.

Hidayat, T.M. (2010). Analisis Efektifitas Pelaksanaan Program Pelatihan Kewirausahaan Pemuda (Kasus di Kabupaten Banyuasin). Jakarta: Program Pascasarjana Program Studi Kajian Ketahanan Nasional

Kartasasmita, Ginanjar. (1996). Pembangunan Untuk Rakyat, Memadukan Pertumbuhan dan Pemerataan. Jakarta: CSIS.

Kartasasmita, Ginanjar. (1996).

Pemberdayaan Masyarakat: konsep Pembangunan Yang Berakar Pada Masyarakat. Jakarta: Badan Perencanaan Pembangunan Nasional. Kirkpatrick, D. L. (2006). Evaluating Training Programs, The Four Levels (3rd ed). San Francisco: Berrett Koehler Publisher, Inc.

Singh NN, Curtis WJ, Ellis CR, Nicholson MW, Villani TM, Wechsler HA. 
(1995). Psychometric analysis of the family empowerment scale. Journal of Emotional and Behavioral Disorders, 85-91.

Simamora, Henry, 1999, Manajemen Sumber

Daya Manusia, Edisi kedua,Cetakan kedua, Yogyakarta: Penerbit STIE YKPN,

Tiwari, Indra P (2013), State welfarism and social welfare in ASIA, Journal of arts and Humanities (JAH), Volume 2 No 2 March 2013, (Proquest) database.

Badan Pusat Statistik (2015). Tingkat Kemiskinan di Indonesia Maret 2015. Jakarta: Berita Resmi Statistik

Badan Pusat Statistik. (2016). Tingkat Kemiskinan di Indonesia Maret 2016. Jakarta: Berita Resmi Statistik

Badan Pusat Statistik. (2017). Tingkat Kemiskinan di Indonesia Maret 2017. Jakarta: Berit Resmi Statistik Keputusan Menteri Dalam Negeri Nomor 53 B Tahun 1993 Tentang Pedoman Program Usaha Peningkatan Pendapatan Keluarga PKK. 